\title{
THE REPRESENTATION OF THE FEMALE BODY IN THE CONTEMPORARY CULTURAL CONTEXT: THE CASE OF HBO'S GIRLS
}

\author{
MARÍA DOLORES NARBONA CARRIÓN \\ Universidad de Málaga \\ narbona@uma.es
}

Received 31 July 2019

Accepted 11 January 2019

KEY WORDS: Representation of female bodies; HBO's Girls; Lena Dunham; beauty standards; celebrity feminism.

PALABRAS CLAVE: Representación de los cuerpos de mujeres; (HBO) Girls; Lena Dunham; estándares de belleza; feminismo de famosos.

\begin{abstract}
Keeping in mind the confusing atmosphere surrounding the contemporary understanding of feminism, and guided by a solid theoretical feminist perspective, the aim of this work is to study how economic neoliberal interests are utilising supposedly feminist ideas to commodify the bodies of contemporary women in different ways. I will highlight how the mass media has become an essential tool to spread confusing messages which try to lead women to think that, by controlling their bodies in order to have particular physical attributes, they will also feel happier and empowered. Afterwards, I will demonstrate how the above-mentioned confusion is also stirred by contemporary celebrities - such as Lena Dunham- who have taken personal advantage of this fashionable feminist trend. To prove my hypothesis, I will develop an analysis of Dunham's representations of female bodies (especially in her TV series Girls) in order to study and reflect on their supposedly feminist foundations. This will lead us to question the genuineness of her self-proclamation as a champion of the acceptance and defence of the ordinary body. I will base this idea on my inference that the motivation of her original portrayal of the female body is rather derived from an economic interest that resembles that proper to the beauty industry against which she is allegedly fighting.
\end{abstract}

RESUMEN: Teniendo en cuenta la confusión en torno al concepto "feminismo" (hoy tan de moda), y con la ayuda de una sólida base teórica feminista, mi estudio plasmará cómo los intereses económicos neoliberales están utilizando ideas supuestamente feministas para mercantilizar los cuerpos de las mujeres contemporáneas de diferentes modos. Empezaré señalando cómo los medios de 
comunicación se han convertido en una herramienta esencial para propagar mensajes confusos que intentan hacer creer a las mujeres que, controlando sus cuerpos para que tengan ciertos atributos físicos, se sentirán más felices y empoderadas. Después pasaré a demostrar cómo la confusión antes mencionada está también fomentada por personajes famosos tales como Lena Dunham, que han sacado provecho personal de la corriente feminista de moda consistente en mostrar alternativas contrarias a los imperativos de belleza patriarcales. Para probar mi hipótesis, llevaré a cabo el análisis de las representaciones de los cuerpos de mujeres realizados por Lena Dunham (especialmente los de su serie de televisión, Girls) para estudiar y reflexionar sobre sus fundamentos supuestamente feministas. Esto pone en tela de juicio la autenticidad de su autoproclamación como abanderada de la aceptación y defensa de los cuerpos normales. Basaré esta idea en mi inferencia de que la motivación de su representación original del cuerpo femenino se basa más bien en un interés económico muy parecido al propio de la industria de la belleza en contra de la cual está luchando supuestamente.

Nothing seems to be more in line with the zeitgeist nowadays than being a feminist. This has been highlighted by specialists such as Catherine Rottenberg (330) or Rosalind Gill -with assertions such as: "Feminism has seemingly moved from being a derided and repudiated identity among young women (Scharff 2013) to becoming a desirable, stylish, and decidedly fashionable one" (611)-, and Jessica Valenti, who summarises this fact in just five words: "Feminists are everywhere these days." Besides, a simple glimpse at famous fashion shows gives that same impression, with -for example- skeletally thin models wearing T-shirts portraying messages like "We all should be feminists." But, as is the case with many slogans, are people really aware of the implications of their content? In this respect, our contemporary society is evidently affected by the confusion created, to a great extent, by the interpretation of the terms "feminist" and "feminism" offered by popular culture, as an outstanding specialist such as Amanda Lotz recognises in her assertions such as: "Confusion and contradiction mark the understandings of feminism in US popular culture" (106), and as I have shown myself in previous studies (Narbona-Carrión 2017a: 51-53; Narbona-Carrión 2017b). Lotz applies her theories to the US context, on which I also focus, but they can be applied to many other countries, thanks to contemporary globalization and 
because, as Gill recognises -agreeing with other experts such as Jessalynn Keller and Jessica Ringrose (2015) and Jessica Valenti (2014)-, feminism is increasingly and globally represented as "cool" by the mainstream media (611). As a consequence of this widelyspread but confusing image of feminism, and, in line with the main subject of this essay, namely the representation of the female body, many people, especially youngsters, may extract wrong inferences from this situation. For example, they may have the misleading impression that simply the fact of having the freedom to wear clothes including the word "feminist" or "feminism," or other garments that leave almost nothing to the imagination and being able to show this on screen prove that feminism has reached some of its primary objectives. ${ }^{1}$ This might give the false impression that women are now enjoying the equality that they have been struggling for over centuries. Besides, we cannot ignore the fact that these "liberties" are not guaranteed worldwide.

This misperception has been perpetuated even by self-proclaimed feminists who defend that femininity is not opposed to feminism. Consequently, they believe that women's effort to follow body-beauty standards and the consumption of the relevant products should not be associated with female weakness or passivity because, instead, the perfection of their physique can lead them to their longed-for empowerment. This is the main idea -for example- of Catherine Hakim's theory of erotic capital conveying that being attractive is one of the main sources of power for women (97), as she portrays and promotes in her book Erotic Capital: The Power of Attraction in the Boardroom and the Bedroom (2011). Similar notions are present in Jennifer Baumgartner and Amy Richards' influential essay "Feminism and Femininity or How We Learned to Stop Worrying and Love the Thong" (2004), which comes to the conclusion that this type of "girlie" feminism is not incompatible with the possibility of being

\footnotetext{
1 In this context, I agree with Angela McRobbie that the prevalence of images of women's naked bodies (even by themselves) "seems to point to the need for more indepth analysis of what this all means culturally" (xx). And this is something that we find, for example, in New Femininities: Postfeminism, Neoliberalism and Subjectivity, edited by Gill and Scharff (2013). Related to this is the frequently sexualised image of many alleged-feminist celebrities: Keller and Ringrose explain how even teenagers are conscious of the contradictions present in "celebrity feminism" and many even challenge postfeminist discourses that "often equate sexualised displays of the female body as indicative of gender equality, actively questioning this logic through their own understandings and experiences of feminism" (134).
} 
political (62). Nevertheless, other feminists, among whom Angela McRobbie stands out, oppose this trend through warning that "women are currently being disempowered through the very discourses of empowerment they are being offered as substitutes for feminism" (McRobbie 49).

In effect, the term "feminism" has always been difficult to define, due to the diversity that characterizes its intrinsic nature (Menéndez 53), and -among other reasons- because, as Valenti explains, "feminist can be a label, a practice and a lens by which we view the word," and "it is not just an identity: it is a movement. It's something that you do" (2014). The complexity of the definition of this concept has been highlighted by other relevant scholars like Rosalind Gill (2007) and Yvonne Tasker and Diane Negra (2007), to cite just a few. The richness of the term is also reinforced by the existence of numerous dictionaries trying to give a clear notion of what it implies; for example, Maggie Humm's The Dictionary of Feminist Theory (2003) or Sarah Gamble's The Icon Critical Dictionary of Feminism and Postfeminism (1999). In this context, Rachel Robinson-Greene has even declared that it is easier to delineate feminism by saying what it is not (18), an idea that does not contradict Valenti's assertion that if there are not certain boundaries for claiming the word "feminist," it becomes meaningless (2014). Besides, trying to counteract its apparently blurring essence, this theorist has offered a basic but quite useful definition of "feminism" as "a movement for gender justice -for social, political and economic equality of all women- and one that recognizes the complexity of women's identities and the intersection of oppressions" (2014). She considers this necessary because, even if we cannot deny that having more people talking and thinking about feminism is positive, "the ubiquity of the word in popular culture, all the people identifying as feminist, that doesn't guarantee progress on the ground" (2014). However, I do not want to be automatically aligned with the introductory studies to feminist scholarship and criticism that, according to Ashli A. Quesinberry, "often provide the reader with the notion that little exists in popular culture that promotes the tenets of feminism" (127). I do nonetheless consider that it is necessary to analyse allegedly feminist cultural products in detail, precisely because I share Joanne Hollows's view that feminism functions in popular culture in a very complex way (Quesinberry 127). In this sense, I also agree with expert Ronnee Schreiber's advice: “It's important for feminists to be able to say 
someone's actions are not feminist or the term loses all meaning and no one knows what it stands for" (qtd. in Valenti). ${ }^{2}$

Consequently, parting from the complicated atmosphere surrounding the contemporary understanding of feminism and guided by this theoretical feminist perspective, the aim of this work is to study how economic neoliberal ${ }^{3}$ interests are utilising supposedly feminist ideas and ideals to commodify the bodies of contemporary women in different ways. I will highlight how the mass media have become an essential tool for spreading confusing messages which try to lead women to think that by controlling and modifying their bodies, they will feel happier and empowered, an idea that is commonly associated with post-feminism. ${ }^{4}$ Afterwards, I will demonstrate how the above-mentioned confusion is also stirred by

\footnotetext{
2 This same critical attitude towards allegedly feminist initiatives can be noticed in the research work of other influential scholars. Among them are Gill and Orgad, who, in "Confidence Culture and the Remaking of Feminism," make us reflect on the supposed feminist motivations of the contemporary "confidence culture" that is supported by the "technology of the self," or "the happy industry" (18).

${ }^{3}$ Gill and Scharff offer this definition of the term "neoliberalism" that might be useful for this analysis: "Broadly speaking it is understood as a mode of political and economic rationality characterized by privatization, deregulation and a rolling back and withdrawal of the state from many areas of social provision that rose to prominence in the 1980s under Reagan administration in the US and Thatcher's premiership in the UK" (5). Quoting David Harvey, they add that it is also "a theory of political economic practices that proposes that human well-being can be best advanced by liberating individual entrepreneurial freedoms and skills within an institutional framework characterized by strong private property rights, free markets and free trade" (Harvey 2). I also recommend Hester Eisenstein's and Catherine Rottenberg's studies of neoliberal feminism to facilitate the understanding of the analysis developed in the present article.

${ }^{4}$ Experts such as Rebecca Munford and Melanie Waters recognise that definitions of "postfeminism" are "manifestly diverse" (13). Gill and Scharff agree with them when they affirm that, even if "postfeminism has become a key term in the lexicon of feminist cultural critique in recent years" (3), it is also affected by the same lack of specificity that affects the term "feminism," and it is used referring to a great variety of meanings. Of the four main interpretations of "postfeminism" offered by these authors, I am mainly using the fourth one, based on Angela McRobbie's study of the term contained in The Aftermath of Feminism. Quoting Gill and Scharff's interpretation of McRobbie's analysis, her work "positions postfeminism as an object of critical analysis [emphasis in the original], rather than as a theoretical orientation, a new moment of feminism or straightforward backlash" (4). For more information about post-feminism, see: Stéphanie Genz and Benjamin Bravon's Post-feminism: Cultural Texts and Theories (2009), and Sarah Projansky's Watching Rape: Film and Television in Postfeminist Culture (2001).
} 
contemporary celebrities, ${ }^{5}$ such as Lena Dunham, who have taken personal advantage of this fashionable feminist trend. To prove my hypothesis, I will develop an analysis of Dunham's representations of female bodies (especially in her TV series, Girls) in order to study and reflect on their supposedly feminist foundations. This will lead us to question the genuineness of her self-proclamation as a champion of the acceptance and defence of the ordinary body. I will base this idea on my inference that the motivation of her original portrayal of the female body is rather derived from an economic interest that resembles that proper to the beauty industry against which she is allegedly fighting.

The problem connected to this "promised land" is twofold. First of all: why do women have to gain that empowerment through their physical aspect and not by other means like improving their intellect, skills, or other virtues? Secondly: what is the (literal and metaphorical) price that they have to pay for trying to become superficially perfect? For centuries, one of the main claims of feminism has been that women have been oppressed by patriarchal parameters at different levels. One of the consequences of that unjust situation was that they were objectified: they were not treated as subjects conducting their own lives, but as objects/bodies to be controlled, observed and even enjoyed. In this context, there is a certain parallelism between women's past and present situation. Furthermore, the contemporary condition is even more dangerous, as this objectification of the female body is offered and advertised as progressive, modern and even feminist; whereas in the past, it seemed in fact more evident that patriarchy was behind the design of that set of restrictive values and conceptions for women. Consequently, in part, I base the objectives of this study on Caslav Covino's assertion that "the recognition that the aesthetic imaginary is a real cultural force should prompt us to view perceptions of the unacceptable body as founded not on private psychological bases but on complex social structures and cultural repressions" (4-5). To fulfil this task, the studies of outstanding feminist scholars who have warned about the subjugation inevitably connected to obedience to

\footnotetext{
5 Keller and Ringrose define the term "celebrity feminism" as "a form of popular feminism made visible recently by young celebrity women eager to publicly claim a feminist identity" (132). They offer as examples of its existence: "Beyoncé's MTV Music Video Awards performance before an illuminated backdrop of the word 'Feminist'," and "Taylor Swift and Jennifer Lawrence claiming allegiance to the f-word" (132).
} 
fashion and beauty standards are very illuminating. Among them are specialists such as Susan Faludi, Naomi Wolf and Susan Bordo, whose resistance to the beauty industry has contributed to the required critical consciousness that I defend in this article. In the subsequent analysis of the controversial TV series Girls (HBO, 20122017), I will also demonstrate how its creator, Lena Dunham, seems not to be coherent and not to have such solid feminist foundations in her representations of the female physique, even if she frequently proclaims herself as a feminist champion of the "ordinary" body, as many TV critics have noted (e.g. Murray 246).

The alliance between neoliberalism and (supposed) feminism is tightly connected to what has been called "post-feminism," and even "neoliberal feminism" (Keller and Ringrose 132), which can be interpreted as a wolf in sheep's clothing promoting that women should "invest" a great part of their energy, time and money in shaping their bodies into perfect ones that may attract people especially the heteronormative male gaze- to the point of alluring them with the intention of obtaining as many advantages as possible. Thus, it can be easily inferred that this leads to a very poor concept not only of women, but also of society in general, whose members are presented as entities who are very easy to manipulate, ready to be abducted by chants of sirens lacking in authentic depth. Besides, as Caslav-Covino declares, "it is thus necessary to develop analyses that continue to 'denaturalize' the normalizing force of the future perfect that the [beauty] industry presents" (6). She agrees with specialists who believe that one of the main tasks of contemporary feminist research is to promote the reflection on the multiplicity of supposedly feminist messages dealing with the perfection of their physical aspects, for example, that are so ubiquitous nowadays. Among them is Melinda Young, who asserts that "for feminism to become more relevant to women, it needs to work toward shaping women's identities around their abilities, not their hips and bellies" (250). Consequently, feminist cultural critics should also facilitate analysis of the supposedly feminist messages which are spread by the mass media, with the intention of helping women to avoid or liberate

\footnotetext{
6 This is the definition of "neoliberal feminism" given by Keller and Ringrose (132): "This version of feminism recognises current inequalities between men and women yet disavows the social, cultural, and economic roots of these inequalities in favour of the neoliberal ethos of individual action, personal responsibility, and unencumbered choice as the best strategy to produce gender equality". See also Eisenstein's article for further information about neoliberal feminism.
} 
themselves from new oppressions that try to subjugate and prevent them from developing their authentic and most valuable attributes. I am convinced that such an initiative would improve women's lives at a practical level, too, for example, reducing the number of cases like that of Cindy Childress. This girl wrote what follows, from the clinic where she was trying to recover from the eating disorders provoked by her obsession with shaping her body according to our contemporary canons of beauty:

Working to be thin diverts my energy from activism and being a social person. To get my life back, I have to give up that ultra-sense of control over the shape and size of my body to 'be' while I do more important things like work on my doctoral degree. To me, fat-positive media, or even a fat-accepting media, will not focus on a body -large or small- because of its shape, but rather on a person". (84)

In effect, Childress is evidently illustrating a reality that Michel Foucault had already described in detail in his book Discipline and Punish: The Birth of the Prison, originally published in 1975, where he explains how, from the classic ages, those in power have tried to impose control on bodies by means of establishing different disciplines with the aim of controlling not only their physical aspects, but also of conditioning their actions to follow their particular interests (136-37). After experiencing the negative consequences derived from trying to discipline her body to the point of becoming seriously ill, as we infer from her testimony, Childress is not promoting simply the portrayal of fat bodies in cultural products -as Lena Dunham does in Girls-, but the necessity for the mass media to focus on whole human beings, and not exclusively on their bodies. This consideration will be relevant in my analysis of this TV series.

\section{ECONOMIC INTERESTS HIDDEN BEHIND ALLEGED FEMINIST MESSAGES}

In the crucial discernment that I am underlining in my study with respect to the distinction of the messages that women receive encouraging them to improve and perfect their bodies, we must include the reflection on who is behind the spreading of those ideas. At present, really powerful companies orchestrate the manipulation of women's interests, not with the mere intention of making them feel empowered, as they advertise, but rather of making them spend their money (besides their time and energy) on the products that they sell. An evident example of this is the extremely well-known slogan of 
L'Oréal products, "Because I'm Worth It,"' created in 1973 by Ilon Specht, profiting from the intensity that the Second Wave of Feminism was enjoying then. However, the real reason why the owners of this trademark tried so hard to encourage and support their potential female consumers was the fact that they had to justify their higher prices in comparison to those of similar products on the market.

L'Oreal and other companies are so assertive and vehement in their advertisements that they might make many women believe that to reach fulfilment, happiness or power depends absolutely on their physical attributes. This problem becomes heightened when entrepreneurs spread these materialistic ideas not only directly with their marketing campaigns, but also by employing less obvious tactics such as sponsoring films, TV programmes and influencers that reach huge audiences of a very wide range of ages. To illustrate this assertion with an example, I am going to comment on one related to the first of the three cultural products that I have just mentioned: it is the case of the film Love on a Diet (2001). As the title clearly reveals, this romantic comedy is about a fat couple who manage to lose weight and, thus, gain love. The moral is clear: if you model your body in a socially accepted way, you will also receive the reward of romantic or love relationships. This lesson does not surprise anyone with its originality, as it is now almost omnipresent, but the discovery that a manufacturer of diet products sponsored it is worrying. This fact reveals that the intention of this film was to propagate the harmful idea that "the [diet] pill becomes a powerful tool to help girls find their Prince Charming" (Lee 96), with the evident objective of boosting its creator's profits.

A very similar example -from the many that might be offeredderives from the fashion industry. In September 2014, Karl Lagerfeld can be said to have inaugurated a tendency that has been sustained since then with the outstanding variety of (allegedly) feminist merchandise that exists today. ${ }^{8}$ In his Chanel show at Paris fashion week, emaciated models (thanks to the impositions of the contemporary standards of beauty), wearing astoundingly pricey

\footnotetext{
${ }^{7}$ For more information about this slogan, visit https://www.lorealparisusa.com/about-loreal-paris/because-youre-worth-it.aspx

8 To see an example of the offer of feminist merchandise, visit https://www.huffingtonpost.com/entry/feminist-tshirts_us_58bee403e4b0d8c45f46d909?guccounter=1
} 
clothes and accessories, walked down the catwalk shouting and displaying banners with purportedly feminist messages such as: "Be Your Own Stylist," "Free Freedom!" "History Is Her Story," "We Can Match the Machos," "Boys Should Get Pregnant, Too," "Ladies First," "He for She" (echoing Emma Watson's UN campaign supporting equality between men and women ${ }^{9}$ ), "Féministe Mais Féminin," or "Be Different." This scene exemplifies what Roxane Gay criticises as being "fashionable feminism" in which women who are apparently asking for equal rights to men's "embody the standards we're supposedly trying to challenge."

In addition, as Jess Cartner-Morley affirms, it is difficult to believe that Lagerfeld was mainly moved by feminist intentions when he organised this model army chanting for women's freedom. This is evident, especially, if we take into account, among many other reasons, the fact that he once confessed that everything he says is a joke, adding "I am a joke myself" (Smith); and even more so if we remember the fact that he once declared that "nobody wants to see curvy women on the runway" (Kirkova); or that, in response to the social criticism of the presence of size-zero models in fashion shows, he reacted by considering this just the whimsical reaction of "fat mommies with bags of crisps" (Cartner-Morley). Nevertheless, this might not be so evident for those who follow the commentaries of supposedly specialised journalists who interpret literally the abovementioned "feminist" messages widely disseminated by popular mass media. Among the many examples that I have found to prove this assertion, and continuing with the case of this famous fashion designer's initiative, I will focus on the commentaries of Trish Halping, editor-in-chief of Marie Claire. Halping, influenced by the fact that the founder of the firm, Coco Chanel, defended feminist values, considered that the show was emphasizing the fact that feminism was enjoying a very good year, thus interpreting Lagerfeld's feminist pantomime as an authentic effort to promote women's equality (qtd. in Topping). In more up-to-date mass media, far more widespread than paper magazines, the show was equally valued, as the words of the blogger and editor Amy Odell portray in her tweet

\footnotetext{
${ }^{9}$ To see the whole UN speech in defence of feminism given by Watson just a few days before this fashion show, visit http://www.unwomen.org/en/news/stories/2014/9/emma-watson-gender-equalityis-your-issue-too. Watson's speech has been criticised by postcolonial feminists, who did not feel included in it (Rottenberg 331).
} 
published in Cosmopolitan.com: "Awesome feminist statement at Chanel -for once do not care a flip about the shoes because THIS IS EVERYTHING."

For some critics, this "fashionable feminism," even if it seems superfluous -and, consequently, it may fall out of style as fashion does- and even if it may lack some of the main requirements to be considered "authentic" (using Keller and Ringrose's terminology 133), it might be fulfilling the task of making it "more visible within popular culture" (Keller and Ringrose 133). In connection to this idea, they add that "popular feminisms have a lengthy history within feminism and have been crucial in making feminist discourse accessible and relevant to those outside the ivory tower (Farrell 1998)" (134). On the other hand, these scholars add that, for other women, feminism should not be simply a fashionable tendency but should involve a long-standing commitment (133). It is not possible to extend this discussion now, but this double interpretation should at least be mentioned here.

\section{POLITICAL FEMINIST INITIATIVES VS. SUPPOSEDLY FEMINIST CULTURAL PRODUCTS}

Political feminist interest can be found in the fight against the objectification of women's bodies that has traditionally constituted not only one of the main objectives of the theoretical feminist debate, but which has also been defended in practice, for example, by second wavers. They denounced the idealization of the feminine body and the patriarchal impositions connected to the accepted and recommended standards of beauty that transformed women into mere objects for the pleasurable observation of the male gaze. As Fiona Carson affirms, after more than four decades of fighting against those precepts, the vitality of those beauty stereotypes and norms is still present and even stronger (118). A representative case of those activist initiatives was the 1968 protests against the Miss America Beauty Pageant, a contest which still exists and which represents a vivid symbol of the enormous importance that society bestows on the external appearance of women. ${ }^{10}$ Equally relevant have been the British feminists' demonstrations against the British pop artist Allen Jones's "women-as-furniture" artworks that

\footnotetext{
10 This is so even if current beauty pageants take also into consideration other aspects which do not exclusively depend on women's physical aspect. This might be seen as an improvement, but, on the other hand, it is evident that participants are required now to be even more perfect.
} 
consisted of sculptures of almost naked women that served as pieces of furniture. Hard as his declarations are to believe, Jones has defended himself from the accusations of feminist activists by declaring to be on their side with assertions like the following one: "I was brought up a socialist and I think of myself as a feminist and I don't need to defend my political stance" (Wroe). Hence, Jones is here portraying and perpetuating the confusion associated with contemporary feminism that I have explained before. And this is what Marco Livingston's interpretation of Jones's artworks does, too, when he considers them not as symbols of the objectification of women, but as ironic artistic elements parodying men's expectations, as we can see here:

More than three decades later, these works still carry a powerful emotive charge, ensnaring every viewer's psychology and sexual outlook regardless of age, gender or experience. But a few moments of reflection should make it obvious that these works are manifestations of fantasy and the imagination, and that they poke fun at male expectations. (160-61)

These confusing representations of what feminism is are affecting other cultural products which are even more influential, such as films and TV programmes. In parallel with the cases of Lagerfeld's fashion shows or Jones's artworks, popular interpretations of these cultural products tend to offer the oversimplified notion that the mere apparent advocacy of women in them is a consequence of the achievements of feminism. Thus, they ignore the fact that those representations of women might be precisely damaging their image by reinforcing and perpetuating patriarchal impositions. Equally deceitful can be the self-proclamation as feminists of certain TV series creators whose programmes might simply have the same economic purposes as those of Lagerfeld's fake feminist parade or Jones's artworks, ${ }^{11}$ as notable scholars like Robin Nelson highlight (62). In this same line, Angelica Jade Bastién aptly explains the financial temptations that lie behind certain supposedly feminist TV programmes:

\footnotetext{
11 We could add to these examples bell hooks' interpretation of some of Beyoncé's supposedly feminist works. Concretely, her response to Beyoncé's visual album, Lemonade, was: " WOW-this is the business of capitalist money making at its best." Keller and Ringrose also echo the opinion of feminists who consider that media representations of celebrities -among them Beyoncé - as feminists contains contradictory messages (133).
} 
When a series is described as "feminist," it's as if it earns a gold star signifying its importance. Such a designation also lets it be marketed as such - often without sufficient attention paid to its aesthetic values. Most troubling is how the rush to crown shows feminist (or not) flattens criticism of the shows themselves and alludes to how a political movement has become a marketing tactic in mainstream circles.

Taking into account Bastién's warning, we should not be misled by the fact that there exist many contemporary TV series in which female participation is substantial, not only in their fictional characters, but also as regards their creators, directors and producers. ${ }^{12}$ First, because the predominant presence in both TV fields is still masculine, as specialists such as Deborah Philips and Robin Nelson highlight; and because the existence of more, new and diverse female characters -which is positive- can also respond to mere marketing tactics with the intention of reaching a wider range of viewers and, consequently, increasing the producers' profits.

Added to this, the famous Bechdel Test might have considerably led to this type of erroneous identifications of the feminist nature in cultural products. Its lack of scientific basis is present from its very origin, which is the mere conversation between two characters in a comic strip titled "The Rule," of Dykes To Watch Out For, a 1985 comic created by Alison Bechdel. The author has even publicly recognised that her dialogue did not have the pretensions that it has later been assigned. Accordingly, she showed her surprise when she realised the importance of her fictional speech, which is used even in web pages created to analyse the "feminism" of films (e.g.: The Bechdel Test Movie List). In "The Rule," two women are considering the possibility of going to the cinema. One of them explains that she only goes to a movie if it "satisfies three basic requirements," which are: "It has to have at least two women in it" who have to "talk to each other" about "something besides a man."

It is evident that these are insufficient reasons for a film or a TV series to be considered feminist, and the problem is that similarly

\footnotetext{
12 Take as representative cases of this assertion the following TV series, among others: Two Broke Girls (CBS, 2011-), by Whitney Cummings; Don't Trust the B in Apt. 23 (ABC, 2012-2013), by Nahnatchka Khan; Broad City (Comedy Central, 2014-), by Ilana Glaze and Abbi Jacobson; Unbreakable Kimmy Schmidt (Netflix, 2015-), co-created by Tina Fey; Inside Amy Schumer (Comedy Central 2013-), by Amy Schumer; Girlfriends (UPN, The CW, 2000-2008) by Brock Akil; and Living Single (Fox, 1993-1998), by Yvette Denise.
} 
poor barometers are applied to particular cultural products, such as the TV series on which I am focusing this essay, Girls. Lena Dunham contributes to this confusion when she answers the question whether her series is feminist or not by declaring: "How could a show about women exploring women not be?" (Clark). In effect, this TV series stars not only two but four women (hence its title, Girls); its creator, producer and protagonist, Lena Dunham, has declared herself not only a feminist, 13 but a "rabid feminist" (qtd. in Nash and Grant); and many of the subjects talked about can be labelled as typically feminist too (e.g.: abortion, free love, divorce, or sexual abuse, among others). Added to this, the marketing of Girls insistently promotes it as an innovative, ground-breaking cultural product (supposedly) starting out from its creator's intention to offer a realistic and feminist vision of the female millennials' world.

However, it is important to not completely trust Dunham's words without analysing her creation in a detailed way because, as Bastién warns, "we're living in times in which simplistic readings aren't just intellectually dishonest, they're dangerous." After having followed and analysed Dunham's cultural products for years, my inference shared by authors like Brian McGreevy, 2013)- is that she is not immune to the exclusively commercial temptations that are behind all types of businesses, the mass media being no exception, as Bastien has highlighted. To prove this, it should be borne in mind that the television network where it is broadcast (HBO) realised, after the overwhelming success of its Sex in the City (1998-2004; winner of 7 Emmy Awards and 8 Golden Globes) that TV series about women and for women constituted a financial goldmine. Consequently, when this series came to its end, HBO become aware of the benefits derived from this goldmine and looked for something similar to and, at the same time, distinct from its precursor, so as to give the impression that it was not a simple sequel or copy of the extremely well-known Sex in the City.

Therefore, they designed a programme starring four white, heterosexual, able-bodied, cisgender women (again, and as is common in post-feminist TV series) living in New York (though not in Manhattan like their older counterparts, but in the more 'alternative'

\footnotetext{
13 Even if Lena Dunham defines herself as a feminist, she frequently describes this in frivolous ways, for example, offering as a solution for the improvement of women/men relations the fact of having "someone they could pay for talk therapy" (qtd. in Clark 2013).
} 
Brooklyn), who are younger than the previous ones (as the title makes clear) and who are situated in the vital phase of looking for a job (as opposed to the women of Sex in the City, who are normally portrayed spending their salaries on different consumer items). As a result of these differences, the attitude with respect to a variety of everyday situations of the four girls differs also considerably to that of the (also) four female protagonists of Sex in the City. There are many other aspects that we might comment on in reference to the comparison between these two TV series, and there are scholarly works on this topic, such as those Rory Carroll, Emily Nussbaum or that of Meredith Nash and Rubi Grant, aptly titled "TwentySomething Girls vs. Thirty Something Sex and The City Women" (2015). They all share the inference that HBO's intention was to demonstrate that Girls was offering something new with a programme that departed from the consumerist and idealised vision of the Sex in the City women's lives. The marketing of Girls was, thus, based on its promotion as an apparently innovative and groundbreaking programme with which female millennials could identify, proclaiming itself to be (in its protagonist's words) "the voice of a generation" (pilot episode).

Nevertheless, the lack of realism of Girls has been emphasised by many viewers who have declared that they do not identify with the young people portrayed in the series; by others who show their surprise, for example, that these four girls and their friends can live in apartments whose rents are paid even when they lack proper jobs; or by youngsters from different ethnic minorities who complain that there are only white characters in the programme (Watson 145-65). Equally doubtful is Dunham's assertion that she is a feminist and that this is the ideology that gives form to her programme when, on the contrary, there are many attitudes that are far from representing any genuine striving to improve the lives of (all types of women, which is one of the most basic principles of feminism in its diverse forms, versions and epochs.

Considering the huge capacity of television to influence society, as many reputed scholars have demonstrated (Carson and LlewellynJones, Baker, Menéndez) the spreading of these confusing ideas about feminism is not a trivial matter. This situation is aggravated by the fact that Time magazine has considered Lena Dunham as one of the 100 most influential people at present (Danes), and critics recognise that "Lena Dunham is everywhere these days" (Clark). It follows that the analysis of her cultural products thus becomes 
essential if we are to determine how her influence is actually exerted, in what directions and with what intentions. Her self-proclamation as a feminist should, rather, be interpreted as an opportunistic choice that reminds us of "celebrity feminism" (which has already been discussed), or of what Gay has termed "fame-inism" to make reference to the feminism of celebrities, which has questionable authenticity and doubtful political worth. Specialists like Kate Erbland situate Dunham in that context, with assertions like the following: "While Dunham continues to trade on her feminist identity as part of her professional and personal bonafides, she is consistently unable to meet that kind of standard" (Erbland).

\section{FEMALE BODIES PORTRAYED BY FEMINIST ARTISTS VS. THEIR REPRESENTATION IN GIRLS}

From the many aspects we can pay attention to in order to study Lena Denham's alleged feminism, I am going to focus on the body politics that her famous TV series Girls illustrates, ${ }^{14}$ paying special attention to its protagonist, Hannah Horvath, whose identity is very easily confused with that of the actress that incarnates her, Lena Dunham (a tactic that I consider that she has used on purpose, for marketing reasons). There are thousands of testimonies (including those of Dunham herself ${ }^{15}$ ) that situate this creator's representations of the female body as a subject instead of as a typically objectified one, to which we can add a number of opinions considering her as a champion of body acceptance, ${ }^{16}$ as her protagonist is not as slim as typical white female actresses. In this sense, it might be tempting to automatically situate Dunham's intentions in the line of other women artists who have fought for the distancing of their portrayal of women from patriarchal stereotypes which have traditionally turned them into the object of the male gaze, thus satisfying their contemplation of standard beauty. Those artists have explained their

\footnotetext{
${ }^{14}$ I have written on this subject in previous studies, in the wider context of the analysis of Lena Dunham's works.

${ }^{15}$ Consider, for example, this assertion of Dunham highlighting this idea: "Let's get something straight: I didn't hate what I looked like - I hated the culture that was telling me to hate it" (qtd. in Brady).

${ }^{16}$ In proof of this, I cite two examples. The first is Karren Brady's assertion: "Whatever you think of Lena Dunham, you should praise her for body positivity"; and the second is Maria San Filippo's comment: "Lena Dunham has devoted the past several years to making her flabby torso and her personal humiliations (sexual and otherwise) into feminist political performance (43).
} 
original representations with coherent feminist theories derived from specialists like Julia Kristeva, who, in writings such as Powers of Horror: An Essay on Abjection, defends the representation of women's bodies as subversive, grotesque and resistant to all categorizations; or the French philosopher Luce Irigarary, whose works associate the female body with fluidity, to an open recipient without concrete outlines that includes its vile and less pleasant aspects.

Among those artists is situated Helen Chadwick (1953-1996), who includes abject representations of the female body in her artworks that portray, as we can see in Of Mutability (1989), for example, photocopies of her naked body spitting fruit or surrounded by animal corpses, thus opposing the typical painting of feminine nudes. When asked about the intentions of her cultural products, Chadwick offers well-founded answers that explain her subversions as attempts to dissolve the limits that constrain women. Not for nothing has Chadwick been considered by Carson as one of the first artists to use the abject and recognise its power to break categories and question the dominant formations of certain ideologies (124). Even if the physique of Chadwick resembles the ordinary body of Hannah Horvath a lot, the reasons behind both representations are far from analogous. To give one example, Dunham has explained her "subversions," simply underlining her intention of being original; she has literally declared: "It's not interesting for me to make art about things we're all okay with. I make art to explore our darker areas. When what I'm doing begins to feel old and tired and socially acceptable, maybe I'll move on to other topics" (qtd. in Clark). This assertion makes no reference at all to her feminist intentions, and, now that feminism is becoming not only "socially acceptable" but even fashionable -as this study underlines-, should we expect Dunham to move on to "other topics"? Dunham has also shown her aversion to being asked about her frequent nudes in the series, for example, by saying: "If I could abolish one question, it would be "Why are you naked on TV so much?' I don't know. Use your imagination" (qtd. in Carlson). Are there any hints of feminist foundations either in this attitude or in the answer to the question?

A similar case to that of Chadwick is illustrated by Jenny Saville (1970-), whose portrayals of women's bodies (sometimes her own body) again resemble the body of Hannah Horvath. However, Saville (like Chadwick) seems to do so with the clear intention of illustrating a more authentic identity of women, thus departing from the idealised vision of the female naked body proper of masculine 
perspectives. There are many more women artists who, in the same ideological line of Chadwick and Saville, represent abject images of the female body, as Rosemary Betterton details in her book An Intimate Distance (1996). This tendency is also shared by collective artworks like those of The Ardorous, a group of artists who explain, for example, regarding one of their exhibitions:

This exhibit aims to create a new landscape, a Gynolandscape, which rejects the classic phallocentric narrative of sex and sexuality of the female body. Gynolandscape questions our current Western ideology of "femininity" and demonstrates how a new generation of female artists from diverse backgrounds are paving the way to a more fluid future. The works in this show are produced by female artists from diverse backgrounds ranging in ages 16-50 that illustrate their struggle with identity and sexuality in the context of femininity. ("Scenes from the Gynolandscape")

Again, such solid arguments to defend unconventional representations of female naked bodies cannot be found in Lena Dunham's statements.

Notwithstanding these examples belonging to high art, as Carson explains, it is rather in low art where we can more easily find examples of representations of female bodies that share many characteristics with the grotesque and carnivalesque body (125). To corroborate her opinion, Carson supports it with the testimony of Mary Russo, the author of The Female Grotesque (1995), who justifies the use of those unconventional female bodies with the attempts of their creators to improve their social context: "The grotesque body is open, protruding, irregular, secreting, multiple, and changing; it is identified with non-official 'low' culture, or the carnivalesque, and with social transformation" (qtd. in Carson 125). TV programmes are included in this low-art classification and, more specifically, TV series and sitcoms, coming closer to the nature of the cultural product that we are focusing on in this essay, Girls. Amanda Lotz considers that it is precisely the comedic genre which facilitates the presence of innovating and ground-breaking women, basing this assertion on the views of other specialists such as Llewellyn Jones, Bonnie J. Dow, Patricia Mellencamp, Kathleen Rowe and Lauren Rabinovitz (111). Rowe goes even further when she affirms in The Unruly Woman that female comedic characters have the potential to destabilise the idealisation of feminine beauty (qtd. in Carson 125). To prove her hypothesis, Rowe uses examples of female characters that represent a positive alternative to those which have traditionally 
followed patriarchal impositions. Among them is Roseanne, of the eponymous series starring her (1988-1997) and who is portrayed as a plump, but also fun, self-confident, smart and mordant woman; and Dawn French (co-protagonist of French and Saunders, 19872007), who also shows a positive view of women, demonstrating that it is possible to be fat and cute as well as intelligent and amusing.

The above-mentioned examples belong to previous decades and are clearly connected to the feminist intention of liberating women from repressive rules governing women's bodies. Those characters demonstrate not only that it is not impossible to ignore societal beauty norms, but also that it is possible to have a fulfilling life inside of a fat body. When I move my analysis forward to the present, centring my attention on the TV series Girls, I lose track of that feminist goal. This might be explained by the fact that in our predominantly neoliberal context, almost no product can be immune to the economic interests that dominate the market, as we have demonstrated previously with different examples taken from the fashion world, from the beauty industry, and even the celebrity context. However, this should not be considered as a valuable excuse for a self-proclaimed (rabid) feminist artist. Lena Dunham's doubtful feminist intentions are detected in the analysis of different themes connected to her own person and her cultural products, as I have shown in previous studies (Narbona-Carrión 2017a; NarbonaCarrión 2017b), but her incongruity seems especially evident in her representation of the female body in Girls. Her lack of undoubtedly feminist basis is apparent, for example, when she is given the opportunity to justify the originality of her representations of her unconventional naked body and the reasons why it is so frequently shown in her series even in very unlikely situations. Instead of founding her answers on feminist reasons, she usually shows disdain or recognises that she doesn't know why and invites interlocutors to use their imagination (as I showed previously), or answers these recurrent questions with evasive assertions like the following: "Life is too short to explain why I appear naked in the series"17 (Heti) or "It didn't occur to me that in the first season, TV critics and people on the Internet would be seeing this" (Golembewski).

There is another compelling reason to doubt the authenticity of the feminist intentions of Lena Dunham's representation of female

${ }^{17}$ My translation from Spanish. 
bodies in Girls. Dunham has declared herself a champion of the acceptance of the "ordinary" female body to the point of declaring that if she woke up with the body of a Victoria's Secret model, she would ask a doctor to help her to recover her previous physique (qtd. in Clark). But the discomfort of her protagonist, Hannah Horvath (whose experiences are based on those of Dunham's, as she has affirmed repeatedly), with respect to her physique is frequently shown in Girls. This is evident even from the pilot episode, when Charlie (the boyfriend of Marnie, one of the protagonist's friends) compares his girlfriend and Hannah to two angels and the protagonist reacts saying crankily that she might represent a "fat baby angel," thus utilising the irony and humour that characterise postmodern culture to laugh at herself. ${ }^{18}$ In episode 3 of the first season, there is another example of this attitude of repudiation of Hannah's external appearance when she explains to Adam (her boyfriend) that she started tattooing her body as an alternative means to have power over it after having realised that she was not able to control its weight. In episode 8 of that same season, as her relation with the thin and stocky Adam consolidates, we see her making efforts to keep fit, taking up exercise and improving her eating habits, though not very successfully. From examples like these, added to the many occasions on which Hannah complains or makes ironic comments about her corpulence and her compulsive eating, the inevitable inference is that this woman does not really accept her body (as Lena Dunham frequently says that she and her fictional alter ego do) and that she is neither happy nor satisfied with it (as Roseanne or Dawn French seemed to be). The impression she gives is that she is resigned to living with it just because she cannot manage to change it, due to the lack of constancy and willpower that characterises her whole life. Consequently, this character is rather reinforcing the postfeminist idea that, in order to have fulfilling lives and not to feel miserable, women have to fight harder in order to fit into beauty standards, instead of showing that they can reach that goal by many other means. ${ }^{19}$

\footnotetext{
${ }^{18}$ Heike Mißler relates this use of humour to the relation of Girls with "the chick formula," too (33).

${ }^{19}$ For example, bell hooks explains how the acceptance of your body has very positive effects on your personality: "Honoring the self, loving our bodies, is an appropriate stage in the construction of healthy self-esteem."
} 
In effect, as the plot develops, the audience can also witness how this hatred that Hannah feels for her body contaminates her whole person, thus offering a very negative image of a plump woman who is also embittered, as some of her assertions clearly demonstrate: "No one can ever hate me as much as I hate myself, okay? So any mean thing anyone can think of to say about me I've already said to me, about me, probably in the last half hour" (qtd. in "Why Girls"). Therefore, these facts lead us to infer that Dunham, with the creation of her protagonist, is - instead of sending a body-positive message - validating Deborah Caslav-Covino's assertion that in our contemporary society, "the unmodified, unimproved body is always a potential violator of the aesthetic stasis upon which happiness depends" (1). Consequently, a logical inference of the audience can be: if a woman with such a body is so unfulfilled and unhappy, we should rather resort to the beauty industry that promises empowerment and happiness by adopting its philosophy and products. As Caslav-Covino explains:

Because embodiment, both social and personal, does feel difficult and painful much of the time, and because the industry's remedies seem to become more and more efficient and effective, the imaginary's visions of the abject body and its own therapeutic powers can seem to call to us as unmediated facts, rather than through a supervisory ideology. (6)

Undeniably, one of the main objectives of feminism is to eradicate the objectification of women's bodies. But we notice how Lena Dunham seems to ignore this basic premise when her protagonist utilises and lets others use her body as if it was just a tool, thus forgetting the significance of herself as entire human being, not limited to a piece of flesh. She seems to ignore the fact that, as Bailey affirms, even if "we cannot live without our bodies, yet we are not just our bodies" and that "the body matters because it physically contains the 'self'; it experiences pain and emotion; [and] it enables thought" (29). This is evident, for example, when she uses her body as an object to have sexual experiences with the exclusive intention of talking about them in the memoirs she is writing, and she does so obeying her boss's orders (season 2, episode 9). With only that objective in mind, at the same time, she does not take into consideration other people's feelings and she has sexual relations with Jessa's half-brother or with her ex-drug addict neighbour, Laird (season 2, episode 3). This objectification of the body is also present in the way in which Hannah repeatedly and blindly follows Adam's instructions and 
allows him to use her body (he does the same with other female characters, such as Natalia ${ }^{20}$ ) as if it was just a blow-up doll to satisfy his selfish sexual fantasies. ${ }^{21}$ Thus, he orders her to adopt certain uncomfortable positions and roles, he asks her to wear a number of disguises, and he surpasses the limits of sexual abuse when he urinates on her in the bathroom without her consent (season 1, episode 8) and when she feels more evidently forced to please his erotic desires. It is difficult -if not impossible- for any critic to see any feminist intention behind the depiction of these types of scenes, especially if we take into account Dunham's recognition that her main artistic intention is simply to "explore our darker areas" in order to show what is not socially acceptable, and that she attributes her success to "exploring beyond the limits of comfort" ${ }^{\prime 22}$ (Clark).

On other occasions, it is Hannah herself who uses her body as a bargaining chip, for example, to thank men for their favours even without being asked to do so. Consequently, it is really difficult to associate her behaviour with that of a genuine feminist when, for example, after being rescued from the motorway by her friend Ray, she provides him a fellatio that he did not demand and did not expect at all. Such was the case that, as he was driving, he was so shocked by the unexpected event that he had an accident (season 5, episode 8).

Nevertheless, these are not the only ways in which Hannah objectifies her body. In season 5 , episode 7 , she is summoned to the office of the principal of the high school where she is working to be reprimanded for her weird and improper professional behaviour. There, instead of trying to solve the problem in a reasonable way, through dialogue, she takes the initiative of doing so by sitting in front of her superior, uncrossing and recrossing her legs without underwear, like Sharon Stone in her famous scene in Basic Instinct.

\footnotetext{
20 See, for example, the harsh and just criticism that the episode titled "On All Fours" (season 2, episode 9) received in Allison Keene's article.

${ }_{21}$ Girls's depiction of male characters is also controversial. As Heike Mißler asserts, "they are cast as most desirable when they assert themselves as old-fashioned alpha males, professionally and/or romantically" (32), and they are normally portrayed as more witty, self-assured and right in their choices than the female characters, who are portrayed in a much more negative way.

22 She frequently achieves this objective, to the point that a viewer has declared, particularly about the episode "On All Fours," that it was "the most uncomfortable half-hour of television I've ever watched" (an opinion which I share) (Keene).
} 
The fact that Hannah gets optimum results from this thousandth utilisation of her body leads to the logical inference that Hakim's theories dealing with women's erotic capital can certainly be usefully applied.

Similar deductions can be derived from Hannah's reaction to sexual harassment at her workplace. In season 1 , episode 4 , she tries to share and compare with her colleagues her impression that their boss touches them more than necessary. They confirm her sensation, but they also justify it and recommend that she accept it. At first, considering her surprise at her colleagues' reaction, it seems that Hannah is going to fight against this intolerable situation. But it is really difficult to understand how this supposedly feminist character ends up accepting the advice of Jessa (one of her friends) advice to keep on seducing her elderly boss so as to report him to the police and obtain financial gain from that accusation. Even if she is not so successful this time, the message conveyed is equally confusing and inconsistent with the feminist orientation of her series that Dunham often highlights in her comments on it.

Besides, as this essay is trying to demonstrate, it is very difficult to believe in the genuineness of those affirmations also when we analyse Lena Dunham's image as a celebrity, being present on the covers of the most famous fashion magazines that promote, precisely, feminine beauty ideals, which she also adopts in her photographs. A simple Google search using the terms "Lena Dunham magazine covers" will generate an amazing amount of examples with looks that have nothing to envy of those of professional models. This fact has been discussed by specialists such as Jessica Ford, who has clearly stated: "While Girls works against depictions of femininity that rely on post-feminist constructions of empowerment, Dunham's star-image utilizes aspects of the fashion industrial complex for her own gain" (1036). This incongruence, especially when she appeared in Vogue with photoshopped pictures, has disappointed some of the followers who used to believe in Dunham's defence of the "ordinary" body. One of the strongest reactions was that of Jezebel.com, which offered $\$ 10,000$ for the original photographs and managed to publish them in comparison with the ones published in Vogue, commenting on Dunham's incoherent behaviour (Coen). Another outstanding example of this type of pictures is present in the magazine 
Glamour,23 accompanying Sheila Heti's article "Lena Dunham on Girls, Talent and Curves" 24 (2014), where she appears as a diva wearing glamorous and luxurious outfits, with designs by Marc Jacobs, Gucci or Dolce and Gabbana, accessories by Solange Azagury-Patridge, and Yves Saint-Laurent shoes. ${ }^{25}$

Equally worrying are Dunham's declarations in the abovementioned article affirming that her decision to become a bodypositive champion was, on the one hand, deliberate, and, on the other, a consequence of her conviction that "that was what people wanted to see" (Heti), which in lay words might mean "what increases Girls' ratings." She adds that, after having assumed that her body was a mere reflection of her lack of willpower and elegance, she decided to give it a new value of which she was previously unaware, and this led her to the use of her physique as an advantageous tool for her work. This instrumental use of the female body not only reminds us of patriarchal traditional oppression, but also of what Angela McRobbie calls the "post-feminist masquerade" (58), referring to women's use of their physical attributes with the intention of obtaining power or social status. McRobbie applies this term to bodies that follow fashionable beauty standards, but I consider that Dunham goes even further, albeit in the same direction, when she portrays a physique which is different, original and non-normative having utilitarian objectives. Added to this, this instrumental use of the female body is in line with Hakim's ideas as previously explained, even if Hakim's promoted bodies obtain their benefits by fostering their beauty, whereas in the case of Dunham it is the unusual characteristics (on-screen) of her body that provides her objectives. ${ }^{26}$

${ }^{23}$ She has more recently chosen this same magazine to appear on its cover unphotoshopped: this is one of the many rectifications of her behaviour that she normally undertakes after being criticised. For more information about this cover of Glamour, see Gabrielle Olya's article.

${ }^{24}$ This is my translation from the Spanish title "Lena Dunham sobre Girls, talento y curvas".

${ }^{25}$ Recently, she has also been criticised for her weight loss, which has been interpreted as a betrayal of her defence of the ordinary body in favour of contemporary fashion dictates. For more information, see Jackie Strause's article.

${ }^{26}$ In this essay, I refer to Dunham's or Hannah's body with adjectives such as "normal" or "ordinary" to indicate that they are so in everyday life, in contrast to the expression "on-screen" which I use here to make reference to fictional programmes. Thus, as Jocelyn L. Bailey affirms, "though it may be statistically average in size and shape, there is nothing more exceptional or subversive in contemporary media than 
Moreover, Dunham employs standard-beauty bodies -the ones typically demanded by the male gaze- in the rest of Girls' female cast, a fact that adds reasons to our disbelief in her genuine feminist intentions in the presence of so much nudity and so many sex scenes in the series. This initiative also widens the niche of viewers of the series, as the journalist Jorge Barbó foregrounds in his article appropriately titled "Why Girls Is Not a Series Only for Girls"27, encouraging boys to enjoy the visual pleasure of observing the "sophisticated" Marnie, the "wild" Jessa or the "exotic beauty" of Shoshana. On the one hand, this promotes a sexualized female ideal that, in Wolf's words, "younger and younger girls are beginning to feel they must live up to" (3) to the point that the latest fashions for seven- and eight-year olds re-create the outfits of pop stars who dress like sex workers (as Hannah also does in Girls to satisfy her boyfriend). In this sense, we should ask ourselves with Wolf: "Is this progress?" (4). On the other hand, Dunham's objective of presenting an original (on-screen) physique when she shows her own body is also facilitated by the contrast that the bodies of those other female characters represent when they are shown together. Nevertheless, this disparity pushes ridicule to its limits, for behind it lies the intention of making the audience laugh at Hannah's body because her evident plumpness is highlighted when it is compared with the thin bodies of her friends. This effect is also reinforced by the weirdness of Hannah's clothes, which are even especially designed and sewn in order not to suit her at all, as Girls' costume designer Jenn Rogien has recognized (Mau).

As Nash and Grant explain, Hannah's unflattering physique, added to her lack of financial stability, flaws, and love failures contribute to Dunham's intention to create a non-aspirational character to attract new audiences that would distinguish her protagonist from those of Girls' predecessor, Sex in the City (979). They also consider that, in contrast to the latter series, Dunham was trying to make her female audience identify with her protagonist, looking for what Rona Murray calls "affective ordinariness" connected to the idea: "Here was a body just like their own onscreen, drawing audience approval and strong points of identification" (249).

\footnotetext{
Lena Dunham's body" (29); but the genuine reasons why she portrays this "exceptionality" are the main point of attention of the present study.

${ }^{27}$ This is my translation from the Spanish title: "¿Por qué Girls no es una serie sólo para chicas?"
} 
However, Hannah is depicted in such an extremely ridiculous manner -grazing the territory of self-parody (Lawson)-, that I consider that it is as difficult to identify ourselves with the idealized and perfect image of the female characters in Sex in the City as with that of Girls' protagonist. And I am making reference not only to the weirdness of her body, but also of the peculiar and unbelievable situations in which it is presented, as Murray also points out. For example, in episode 7 , season 3 , Hannah bicycles a long distance in an uncomfortable bikini and appears wearing it in the streets of the Hamptons without any apparent reason, when the rest of her friends are appropriately dressed; or, in episode 5 of season 2, she appears semi-naked while playing tennis with an occasional lover. These "unordinary" representations of the female body should rather be interpreted as forming part of mere cultural products that increase their marketability precisely because of the shocking effect that they produce in an audience that looks for originality in the programmes they watch. This is the same effect that Lena Dunham herself tries to produce with her provocative presence and external appearance, so frequently that she has managed to almost blur the frontier between her real person and her persona.

\section{CONCLUSIONS}

Taking into account the previous reflections and analyses, it will be less tempting to believe automatically that Lena Dunham centres feminist positions in her representation of the female body. Nobody should be misled by her declarations or by the fact that Girls is broadcast by HBO, a network which boasts about producing quality, ground-breaking and innovative programmes which foster the independence and creativity of its "gifted storytellers" ("About HBO"). According to the analysis offered in this essay, it seems more evident that Lena Dunham's motivations to create the unconventional body (and behaviour) of Hannah Horvath in Girls are -rather than feminist- connected to mere commercial intentions. These intentions are based on her creation, not only of original and innovative body representations and situations (as we have already noted), but also of polemics that have given rise to issues to be discussed both by the audience and by specialized scholars, because as Alberto Rey 
affirms, "there is nothing worse for a TV series than to go unnoticed". 28

In this sense, as a researcher, I have the sensation that I am contributing to Dunham's strategic plan, giving importance to a TV series which stands out more for the discussion that it generates ${ }^{29}$ than for its viewers' ratings, which have been even labelled as "pretty ugly" (Venable). However, I also think that, in order to avoid the manipulation of different social forces, it is our responsibility to analyse cultural products in a way that might contribute to the uncovering of the real intentions that might be hidden behind their external appearance. We should also develop this type of analyses because, as Kathleen Lennon affirms in her description of feminist theories of embodiment, "attention to the body plays a central role in social and political thought." I would like to finish this article with Bastién's positive assertion, which has encouraged me to develop the study that constitutes this article and which I hope might inspire and drive other researchers and specialists to go on with this type of critical work on TV programmes: "The progress made in television in recent years is vital, but if we don't question what we see -either in praising when TV exceeds expectations or holding it accountable when it fails with some nuance- then we won't go much further at all." Convinced of the truth of these words as I am, I invite you to consider my article as an invitation to continue questioning what you see.

\section{WORKS CITED}

"About HBO". HBO. www.hbo.com/about/Accessed 31 Dec. 2018. ASLAV-COVINO, Deborah. Amending the Abject Body: Aesthetic Makeovers in Medicine and Culture. New York: State U of New York P, 2004.

BAILEY, Jocelyn L. "The Body Police': Lena Dunham, Susan Bordo, and HBO's Girls." HBO's Girls and the Awkward Politics of Gender, Race, and

\footnotetext{
${ }^{28}$ My translation.

${ }^{29}$ In effect, since its premiere, in April 2012, "the controversial series Girls has become a hot popular-culture topic" (Watson 145). The most outstanding print and Internet publications have commented on the series, e.g.: the New York Times, The Guardian, Harper's Magazine, the National Review, the New Republic, Huffington Post, Entertainment Weekly, Cosmopolitan, Salon, Slate, Jezebel, the Atlantic, the Village Voice, Grantland and Rolling Stone.
} 
Privilege, edited by Elwood Watson, Jennifer Mitchell, and Marc Edward Shaw. New York: Lexington Books, 2015, pp. 27-42.

BAKER, Chris. Television, Globalization and Cultural Identities. Maidenhead: Open UP, 1999.

BARBÓ, Jorge. “¿Por qué Girls no es una serie sólo para chicas?” El Correo. 22 January, 2014. www.elcorreo.com/vizcaya/ocio/201401/22/serie-irgirl.html. Accessed 30 July 2018.

BASTIÉN, Angelica Jade. "Calling a TV Show 'Feminist' Doesn't Make It Feminist." The Outline.com. 4 Dec. 2016. theoutline.com/post/293/calling-a-tv-show-feminist-doesn-t-make-itfeminist?zd=1\&zi=grsnjlxc. Accessed 29 July 2018.

BAUMGARDNER, Jennifer and Amy Richards. "Feminism and Femininity: Or How We Learned to StopWorrying and Love the Thong." All About the Girl, edited by A. Harris and M. Fine. London: Routledge, 2004, pp. 59-69.

BORDÓ, Susan. Unbearable Weight: Feminism, Western Culture, and the Body. Berkeley: U of California P, 2003.

BRADY, Karren. "Whatever You Think Of Lena Dunham, You Should Praise Her For Body Positivity." The Sun. 14 July 2018. www.thesun.co.uk/news / 6779600/karren-brady-lena-dunham-bodypositivity/. Accessed 20 July 2018.

CARLSON, Erin. "Lena Dunham: 'Girls' Extras Hit on Me, Not 'Ryan Goslins'." The Hollywood Reporter. 14 March 2013. www.hollywoodreporter.com/news/lena-dunham-playboy-interview-girlsextras-hit-me-not-ryan-goslings-428610. Accessed 21 Dec. 2018.

CARROLL, Rory. "Is HBO's New Hit Show a Sex and the City for Recessionera America?" The Guardian. April 21, 2012. http:/ /www.theguardian.com/tv-and-radio/2012/apr/21/sex-inthe-city-iphone. Accessed 19 January 2018.

CARSON, Fiona. Feminist Visual Culture. New York: Routledge, 2016.

CARTNER-MORLEY, Jess. "Karl Lagerfeld's New Look for Chanel: Feminist Protest and Slogans." The Guardian. 30 Sept. 2014. www.theguardian.com/fashion/2014/sep/30/karl-lagerfeld-chanelshow-paris-fashion-week. Accessed 30 July 2018. 
CHILDRESS, Cindy. "Glamour's Portrayal of Queen Latifa: Another Unreal Ideal." In "Is Fat Still a Feminist Issue?" by Karen Ross and Suajata Moorti. Feminist Media Studies, 5:1, 2005, pp. 83-104.

CLARK, Cindy. "Lena Dunham: I'm an Eternal Romantic." USA Today. 14 May, 2013. eu.usatoday.com/story/life/people/2013/03/14/lenadunham-im-an-eternal-romantic/1988565/. Accessed 21 Dec. 2018.

COEN, Jessica. "Here Are the Unretouched Images from Lena Dunham's Vogue Shoot". Jezebel. 17 Jan. 2017 jezebel.com/here-are-theunretouched-images-from-lena-dunhams-vogu-1503336657. 17 June 2018.

DANES, Claire. "Lena Dunham." Time. 18 April, 2018. http:/ / time100.time.com/2013/04/18/time100/slide/lena-dunham/. Accessed 19 June 2018.

DUNHAM, Lena, creator. Girls, HBO, 2012-2017.

EISENSTEIN, Hester. "Hegemonic Feminism, Neoliberalism and Womenomics: 'Empowerment' Instead of Liberation?" New Formations, n.91, April 2017, pp. 35-49.

ERBLAND, Kate. "Lena Dunham Uses Feminism to Market, Not to Lead, and Apologies Don't Fix That- Opinion.” IndieWire. 20 Nov. 2017. www.indiewire.com/2017/11/lena-dunham-murray-miller-feminism$1201899387 /$. Accessed 19 July 2018.

FALUDI, Susan. Backlash: The Undeclared War against American Women. Vintage, 2006.

FARRELL, Amy E. Yours in Sisterhood: Ms. Magazine and the Promise of Popular Feminism. The U of North Carolina P, 1998.

FORD, Jessica. “The 'Smart' Body Politics of Lena Dunham's Girls”. Feminist Media Studies, 16(6), pp. 1029-1042.

FOUCAULT, Michel. Discipline and Punish: The Birth of the Prison. Vintage, 1995.

GAMBLE, Sarah, ed. The Icon Critical Dictionary of Feminism and Postfeminism. Cambridge: Icon Books, 1999.

GAY, Roxane. "Emma Watson? Jennifer Lawrence? These Aren't the Feminists You're Looking For". The Guardian. 10 October, 2014. 
www.theguardian.com/commentisfree/2014/oct/10/-sp-jenniferlawrence-emma-watson-feminists-celebrity. Accessed 19 July 2018.

GENZ, Stéphanie and Benjamin A. Bravon. Post-feminism: Cultural Texts and Theories.Edinburgh UP, 2009.

GILL, Rosalind. "Postfeminist Media Culture: Elements of a Sensibility." European Journal of Cultural Studies 10 (4), 2007, pp. 147166.

---. "Post-postfeminism?: New Feminist Visibilities in Postfeminist Times", Feminist Media Studies 16(4), 2016, pp. 610-630.

GILL, Rosalind and Christina Scharff. New Femininities: Postfeminism, Neoliberalism and Subjectivity. Palgrave Macmillan, 2013.

GILL, Rosalind and Shani Orgad, "Confidence Culture and the Remaking of Feminism," New Formations, April 2017 (91), pp. 16-34.

GOLEMBEWSKI, Vanessa. "Lena Dunham: "When You Turn 30, It No Longer Sounds Insane That You Might Be A Mom”. Refinery 29. Feb. 10, 2016. www.refinery29.com/2016/02/102638/lena-dunham-girls-hbo-endingturning-30. Accessed 29 July 2018.

HAKIM, Catherine. Erotic Capital: The Power of Attraction in the Boardroom and the Bedroom. New York: Basic Books, 2011.

HARVEY, David. A Brief History of Neoliberalism. Oxford UP, 2005.

HETI, Sheila. "Lena Dunham sobre Girls, talento y curvas." Glamour. 28 May, 2014. www.glamour.es/celebrities/noticias/articulos/lenadunham-una-chica-con-las-ideas-claras/19931 (Equivalent in English: www.glamour.com/story/lena-dunham-girls-glamour-cove). Accessed 19 July 2018.

HOOKS, bell. "Moving Beyond Pain.” Bell Hooks Institute. Blog. May 9, 2016. http://www.bellhooksinstitute.com/blog/2016/5/9/moving-beyond-pain. Accessed 21 Dec. 2018.

HUMM, Maggie. The Dictionary of Feminist Theory. Edinburgh: Edinburgh UP, 2003.

IRIGARAY, Luce. Speculum of the Other Woman. Trans. Gillian Gill. Ithaca: Cornell UP, 1985. 
KEENE, Allison. “Girls': Did Lena Dunham Go Too Far?” The Hollywood Reporter. 11 March, 2013. www.hollywoodreporter.com/live-feed/girlsdid-lena-dunham-go-427452. Accessed 22 Dec. 2018.

KELLER, Jessalyn and Jessica Ringrose. "But then Feminism Goes Out the Window!': Exploring Teenage Girls' Critical Response to Celebrity Feminism." Celebrity Studies. 6 (1), pp. 132-135.

KIRKOVA, Deni. "Karl Lagerfeld to be sued by women's pressure group after claiming 'no-one wants to see curvy woman on the runway" 3 Nov. 2013. Mailonline. Accessed 19 July 2018.

KRISTEVA, Julia. Powers of Horror: An Essay on Abjection. Trans. Leon S. Roudiez. Columbia UP, 1982.

LAWSON, Richard. "Lena Dunham Bears It All." The Atlantic. 12 Feb. 2013. www.theatlantic.com/entertainment/archive/2013/02/girlsnudity/318438/ Accessed 22 Dec. 2018.

LEE, Amy. "Love on a Diet (2001): The Film Industry's Negotiation with OverSized Romance." In "Is Fat Still a Feminist Issue?" by Karen Ross and Suajata Moorti. Feminist Media Studies, 5:1, 2005, pp. 83-104.

LENNON, Kathleen, "Feminist Perspectives on the Body", The Stanford Encyclopedia of Philosophy (Fall 2014 Edition), edited by Edward N. Zalta, plato.stanford.edu/archives/fall2014/entries/feminist-body/>. Accessed 19 July 2018.

LIVINGSTONE, Marco and Walter Guadagnini, eds., Pop Art UK: British Pop Art 1956-1972. Milan: Silvana Editoriale, 2004.

LOTZ, Amanda D. (2001) "Postfeminist Television Criticism: Rehabilitating Critical Terms and Identifying Postfeminist Attributes," Feminist Media Studies, 1:1, pp. 105-121.

MAU, Dhani. “'Girls' Costume Designer Talks Season 4 and Why Hannah's Clothes Fit So Badly". Fashionista. 8 Jan. 2015. fashionista.com/2015/01/girls-costumes-season-4. Accessed 29 July 2018.

MCGREEVY, Brian. "Don't Call Lena Dunham 'Brave'." Vulture. 15, Feb. 2013. www.vulture.com/2013/02/dont-call-lena-dunham-brave.html. Accessed 21 Dec. 2018. 
MCROBBIE, Angela. The Aftermath of Feminism: Gender, Culture and Social Change. Sage, 2009.

MENÉNDEZ MENÉNDEZ, Isabel. Discursos de ficción y construcción de la identidad de género en televisión. Palma: U de les Illes Balears, 2008.

MIßLER, Heike. "Of Chicks and Girls": New Femininities in Chick Culture." Rethinking Gender in Popular Culture in the 21st Century: Marlboro Men and California Gurls, edited by Astrid M. Fellner, Marta FernándezMorales and Martina Martausová. Newcastle Upon Tyne: Cambridge Scholars Publishing, 2017, pp. 29-48.

MUNFORD, Rebecca and Melanie Waters. Feminism and Popular Culture. Investigating the Postfeminist Mystique. New York: I.B. Tauris, 2014.

MURRAY, Rona. "A Survivor Just Like Us? Lena Dunham and the Politics of Transmedia Authorship and Celebrity Feminism". Feminist Theory. Vol. 18(3), 2017, pp. 245-261.

NARBONA-CARRIÓN, María Dolores. "Rethinking the Image of Women in Contemporary Mass Media: The Case of the TV Series Girls". Rethinking Gender in Popular Culture in the 21st Century: Marlboro Men and California Gurls, edited by Astrid M. Fellner, Marta Fernández-Morales and Martina Martausová. Newcastle-upon-Tyne: Cambridge Scholars Publishing, 2017a, pp. 49-72.

---. "Las relaciones de amistad entre mujeres en los productos culturales: análisis de la serie de televisión Girls". Oceánide, n. 9, 2017b. http:/ / oceanide.netne.net/articulos/art9-8.pdf

NASH, Meredith and Ruby Grant (2015) "Twenty-Something Girls v. ThirtySomething Sex And The City Women," Feminist Media Studies, 15:6, pp. 976-991.

NEGRA, Diane and Yvonne Tasker. Interrogating Postfeminism: Gender and the Politics of Popular Culture. Duke UP, 2007.

NELSON, Robin. "Performing (Wo)manoeuvres: The Progress of Gendering in TV Drama." Frames and Fictions on Television. The Politics of Identity Within Drama, edited by Bruce Carson and Margaret Llewellyn-Jones. Exeter: Intellect Books, 2000, pp. 62-74.

NUSSBAUM, Emily. "It's Different for Girls." New York Magazine, 25 March, 2012. http://nymag.com/arts/tv/features/girls-lena-dunham-2012-4/. Accessed 19 July 2018. 
ODELL, Amy. twitter.com/amyodell/status/51695509277247897730 Sept. 2014. Accessed 1 August 2018.

OLYA, Gabrielle. "Lena Dunham Speaks Out About Body Confidence After Appearing on Magazine Cover Un-Photoshopped." People. 3 June, 2017. people.com/bodies/lena-dunham-body-confidence-glamourcover/Accessed 22 July 2018.

PHILIPS, "Medical Soap: The Woman Doctor in Television Medical Drama". Frames and Fictions on Television. The Politics of Identity Within Drama, edited by Bruce Carson and Margaret Llewellyn-Jones. Exeter: Intellect Books, 2000, pp. 50-61.

PROJANSKY, Sarah. Watching Rape: Film and Television in Postfeminist Culture. New York: New York UP, 2001.

QUESINBERRY, Ashli A. Feminism, Femininity and Popular Culture. By Joanne Hollows. Manchester UP, 2000. Women's Studies in Communication, 24:1, pp. 127-130.

REY, Alberto. "La Nueva Woody Allen (con perdón)”. El Mundo. 25 Jan. 2013. www.elmundo.es/blogs/elmundo/asesinoenserie/2013/01/25/la-nuevawoody-allen-con-perdon.html. Accessed 19 July 2018

ROBINSON-GREENE, Rachel. "Don't Get Mad at Girls." Girls and Philosophy, edited by Richard Greene and Rachel Robinson-Greene. Chicago: Open Court, 2015, pp. 15-25.

ROTTENBERG, Catherine. "Neoliberal Feminism and the Future of Human Capital," Signs: Journal of Women in Culture and Society, 42:2, 2017, pp. 329-348.

SAN FILIPPO, Maria. "Owning Her Abjection: Lena Dunham's Feminist Politics of Embodiment." HBO's Girls and the Awkward Politics of Gender, Race, and Privilege, edited by Elwood Watson, Jennifer Mitchell, and Marc Edward Shaw. New York: Lexington Books, 2015, pp. 43-61.

"Scenes from the Gynolandscape Opening at Four82 Gallery". Paper. 24 Sept. 2013. http://www.papermag.com/scenes-from-the-gynolandscapeopening-at-four82-gallery-1427097680.html. Accessed 19 July 2018.

SCHARFF, Christina. Repudiating Feminism: Young Women in a Neoliberal World. Farnham: Ashgate, 2013. 
SMITH, Lauren. "Karl Lagerfeld Quotes: The Chanel Genius's Most Epic OneLiners." Glamour. 24 Feb. www.glamourmagazine.co.uk/gallery/karllagerfeld-most-controversial-fashion-quotes. Accessed 9 July 2018.

STRAUSE, Jackie. "Lena Dunham on Weight-Loss Backlash: "As a Woman in Hollywood You Just Can't Win” The Hollywood Reporter. 22 March 2017. www.hollywoodreporter.com/news/lena-dunham-weight-loss-backlashas-a-woman-hollywood-you-just-cant-win-987895. Accessed 19 July 2018.

TOPPING, Alexandra. "Chanel's Karl Lagerfeld Cheered and Jeered for 'Feminist' Fashion Statement". The Guardian. 30 Sept. 2014. www.theguardian.com/fashion/2014/sep/30/chanel-karl-lagerfeldcheered-jeered-feminist-staement-fashion-catwalk. Accessed 19 July 2018.

TRAISTER, Rebecca. All the Single Ladies. Independent Women and the Rise of an Independent Nation. New York and London: Simon and Schuster, 2016.

VALENTI, Jessica. "When Everyone Is a Feminist, Is Anyone?" The Guardian. $24 \quad$ Nov. 2014. www.theguardian.com/commentisfree/2014/nov/24/when-everyone-isa-feminist. Accessed 13 Dec. 2018.

VENABLE, Nick. "The Ratings for Girls Are Starting To Get Pretty Ugly." Cinemablend. 2015. www.cinemablend.com/television/Ratings-GirlsStarting-Get-Pretty-Ugly-70011.html. Accessed 14 July 2018.

"Why Girls Like Hannah Horvath Will Never Be Successful". Thought Catalogue. $20 \quad$ Feb. 2014. thoughtcatalog.com/anonymous/2014/02/why-girls-like-hannahhorvath-will-never-be-successful/. Accessed 19 July 2018.

WATSON, Elwood. "Lena Dunham: The Awkward/Ambiguous Politics of White Millennial Feminism."HBO's Girls and the Awkward Politics of Gender, Race, and Privilege, edited by Elwood Watson, Jennifer Mitchell, and Marc Edward Shaw. New York: Lexington Books, 2015, pp. 145-165.

WOLF, Naomi. The Beauty Myth. How Images of Beauty Are Used Against Women. New York: W. Morrow, 1991.

WROE, Nicholas. "Allen Jones: 'I Think of Myself as a Feminist'." The Guardian. $31 \quad$ Oct. 2014. 
www.theguardian.com/artanddesign/2014/oct/31/allen-jones-i-thinkof-myself-as-a-feminist Accessed 30 Dec. 2018.

YOUNG, Melinda. "One Size Fits All: Disrupting the Consumerized, Pathologized, Fat Female Form." In "Introduction: Gender and the PlusSize Body," by Sujata Moorti and Karen Ross. Feminist Media Studies. 5:2, 2005, pp. 237-260. 